\title{
The Predictive Strength of Perceived Parenting and Parental Attachment Styles on Psychological Symptoms among Turkish University Students ${ }^{1}$
}

\section{Serdar Körük}

Eskişehir Osmangazi University, Turkey, serdarkoruk1989@gmail.com

\section{Abdülkadir Öztürk}

Asst. Prof., Eskişehir Osmangazi University, Turkey, akozturk@ogu.edu.tr

\author{
Ahmet Kara \\ Eskişehir Osmangazi University, Turkey, ahmetkara9126@gmail.com
}

This study aims to investigate the relationships between perceived parenting, parental attachment styles and psychological symptoms among Turkish university students and it also aims to find out which perceived parenting and parental attachment styles predict psychological symptoms which were measured. This study is a quantitative research and uses causal comparative research design. The sample of this study consists of 400 university students. Young Parenting Inventory, Parental Bonding Instrument and Brief Symptom Inventory were used for gathering data. The depressive, hostility and anxiety symptoms were determined as the most prevalent psychological symptoms among the sample. The conditional/achievement-oriented and ruling/former mother perceptions were found as the most prevalent perceived parenting styles for mother and the conditional/achievement-oriented and close/repressed feelings perceived as parenting styles for father. Pessimistic/fearful mother, belittling/captious mother and overprotective/worrywart father were found as the most predictive perceived parenting styles which predict the psychological symptoms in a significant level and in a positive way.

Key Words: parent-child relationship, bonding, cognitive schemes, psychological problems, parental attachment

\section{INTRODUCTION}

There is a general opinion assuming that the interactions with parents in early childhood affect the personality development of the individuals consistent with the children's schematics of the outside world and their psychological adaptation skills. The interactions with parents during infancy and childhood and the attachment styles emerged as a result of these may affect the psychopathology of the individuals in

\footnotetext{
${ }^{1}$ This study was presented at 2th International Eurasian Educational Research Congress.
} 
adolescence and adulthood, and may lead them to show behavioral disorders (Keskin \& Çam, 2008). Considering the developmental periods of the child, there are certain emotional needs that must be met by the parents. These needs being met sufficiently is of great importance for the child to become a harmonious and psychologically healthy individual in the future (Young, Klosko \& Weishaar, 2003).

Attachment that is formed between the child and the primary caregiver parent arises with the need of the child to be close to the person who cares the child. Attachment is defined as a consistent and continuous emotional bond that becomes especially evident in the events that the child feels stressed and in danger (Thompson, 1991). According to attachment theoretician, the types of the attachments formed in the early ages may affect the relationships in adolescence and adulthood and negative types of attachments may be indicators of psychopathology (Kesebir, Özdoğan \& Kavzoğlu, 2011). Bowlby (1969, 1973) examined childhood attachment patterns for the first time and he developed a foursome model according to the caring or protective behavior of the parents. This model is explained as; 1) optimal parenting (high care and low protection), 2) neglectful parenting (low care and low protection), 3) affectionate constraint (high care and high protection), and 4) affectionless control (high protection and low care). Ainsworth, Blehar, Waters \& Wall (1978) have grouped the types of children's attachment under three titles; secure, anxious and avoidant. For the formation of a secure attachment, a child's needs should be continuously met by the parent who responds consistently and who provides accessible and sensitive care. The parent's repudiative, negligent, insensitive, overly intrusive and inconsistent behaviors will cause anxious or avoidant attachments, which are insecure attachment types, that may cause the formation of a negative self-model, where the child perceives the others unreliable, inconsistent and cold (Rothbard \& Shaver, 1994). According to the triple model of the Ainsworth et. al. (1978), anxious attachment is related to anxiety disorders and depressive disorders, whereas avoidant attachment is related to behavior disorders, somatic disorders, and other outward pathologies (Kesebir et al., 2011). Bartholomev and Horowitz (1991) investigated the types of attachment in adulthood and unlike the threesome model of the childhood, they have formed a foursome model in which individual's self-image interacts with the image of the others. This model explains secure attachment, dismissive attachment, preoccupied attachment and fearful attachment types. Secure attachment is formed by positive self - positive others, dismissive attachment is formed by positive self - negative others, preoccupied attachment is formed by negative self - positive others and fearful attachment is formed by negative self - negative others combinations.

According to Bowlby (1969), the repeating behavior patterns of the parents, who are the attachment figures in the early childhood, form the mental schemas of the children. Since the schemas that the children has formed based on the relationships with their parents are the base of all the schemas related to the outer world, the individual's psychological health is negatively affected with the emergence of incompatibly formed schemas in the following years (Bowlby, 1973). The repeating behavior patterns of the nursing parent, who is the attachment figure in the early childhood, form the mental schemas of the child, which will be used in particular cases, expectations and beliefs and these schemas build internal working models that will shape child's close relationships 
in the following years. These internal working models are automatically activated in situations inducing stress, anxiety and fear and give direction to the behavior of the individual (Pierce, Baldwin \& Lydon, 1997). According to this model, while the individual responds to particular cases in the individual's social or close relationships, the individual is affected from the interaction patterns with the individual's principal caregiver (Bowlby, 1979). The schemas such as the individual is valuable and important, the people around the individual are supportive and responsible, and the environment is safe, are formed in the baby's mind depending on how the primary caregiver has met the needs of the baby. The studies conducted on parenting perception grouped these perceptions under various titles: affectionate/accepting, controlling, rejectionist, pessimistic-anxious/disastrous, punitive, participative and neglecter (Chorpita \& Barlow, 1998). It is well known that high levels of affectionate/accepting and some level of controlling and participative parenting perception are required for psychological health and adaptability to the surrounding environment (Baumrind, 1991). At the same time, many studies emphasized that having high negative parenting perceptions causes various sentimental, mood, and anxiety disorders (Hudson \& Rapee, 2001; Steinberg, 1994). There are many studies underlining the importance of parenting styles and parenting perceptions that are formed as a result of them on the psychological symptoms of adolescence (Perris, Arindel \& Eiseman, 1994). Harris and Curtin (2002) and McGinn (2005) have conducted studies examining perceived parenting and depression symptoms, Gastel, Legerstee and Ferdinand (2009) have worked on perceived parenting and anxiety disorders, and Kim and Yoo (2013) have studied on perceived parenting and attention deficit/hyperactivity. As a result of these studies, it has been found that overcontrolling, critical and punitive and uninterested/depriving parent perceptions play a significant role especially in the formation of depression and anxiety. The study conducted by Hale, Engels and Meeus (2006) on Dutch adolescents revealed that the rejection and alienation that adolescents have perceived from their parents is positively correlated with their overall anxiety disorder symptoms' scores. In the studies conducted on university students, it has been found that low perceived parental interest and high perceived parental control is a strong predictor of individuals' depressive symptoms (Harris \& Curtin, 2002; Lizardi et al., 1995).

The appearance of psychological symptoms is common during the period of university covering the period between puberty and young adulthood (Bos, Huijding, Muris, Vogel \& Biesheuvel, 2010). In a study conducted with university students, it has been found that the level of prevalence of depression, anxiety, and hostility was high (Kim, 2003). Mood and anxiety disorders are among the most common major mental health problems encountered in adolescence and young adulthood (Dopheide, 2006; Pachler \& Hamrin, 2005; Rapee, Spence \& Cobham, 2000). It is known that the prevalence of depressive symptoms varies between 5\% and 20\% in adolescence (Saluja et al., 2000). Demirel, Eğlence and Kaçmaz (2011) have investigated the psychological symptoms of university students and the most common symptoms were found to be hostility, obsessivecompulsive disorder, paranoid ideation, depression and anxiety symptoms. In another study conducted by Akpınar and Saatçi (2007) on university students, obsessivecompulsive symptoms, paranoid ideation and sensitivity in interpersonal relationships 
were found to be the most common psychological symptoms. During this period, there are some resources that nourish psychopathology. These are: economic and relational problems in families, mental health history of family members, problems with friends, romantic relationship, dating difficulties, social isolation and withdrawal (Ulusoy, Demir \& Baran, 2005). It is known that the malfunction of the parent-individual and peerindividual relationships is the most important factor increasing the psychopathology (Conger \& Ge, 1999). Accordingly, the meanings assigned to the parental behaviors by the children and how they affect the children may vary as well. Some studies revealed that in the culture of the Far-East the supervision and control applied to the child are perceived by the child in a positive way, whereas in European culture the supervision and control mechanism applied to the child are perceived as a rejection of the parents and lack of parental love (Kağıtçıbaşı \& Öztürk, 2010). The discovery of the close relationship between early childhood parent-child interactions and the psychological health of the individual requires more detailed analysis of perceived parenting and parental attachment styles and multi-dimensional analysis of their relationships with psychological symptoms.

\section{Problem Statement}

This study aimed to determine the relationship of psychological symptoms with various factors by examining the university students' parental attachment styles and perceived parenting.

\section{Sub-Problems}

The research questions of the study were set as below:

1. Do parenting perceptions of university students predict the psychological symptoms that they have?

2. Do parental attachment styles of university students predict the psychological symptoms that they have?

\section{METHOD}

\section{Research Design}

This research is a quantitative study, examining the relationships among students' perceived parenting, parental attachment styles and psychological symptoms using the causal comparative research model. Causal comparative research models are the research models aiming to determine the existence and/or the degree of the correlation between two or more variables. Even though causal comparative model does not provide a real cause-effect relationship, it allows to predict a variable if the status of the other is known (Karasar, 2006). While forming the sample, the selection of the students was performed by convenience sampling. In this study, parenting perceptions and parental attachment styles were determined as independent variables, psychological symptoms were determined as dependent variable of the research.

\section{Research Sample}

Gender of the students, faculties of the students participated in the study, and the students' year of study distribution are given in Table 1 . 
Table1: The Distribution of the Research Sample

\begin{tabular}{llll}
\hline Variables & & Number & $\%$ \\
\hline \multirow{3}{*}{ Gender } & Male & 100 & 25 \\
& Female & 300 & 75 \\
& Sum & 400 & 100 \\
\hline \multirow{4}{*}{ University students' faculties } & Education & 234 & 59 \\
& Administrative and Economic Sciences & 56 & 14 \\
& Science and Art & 49 & 12 \\
& Dentistry & 61 & 15 \\
& Sum & 400 & 100 \\
\hline \multirow{4}{*}{ Students' year of study } & Freshman & 76 & 19 \\
& Sophomore & 90 & 23 \\
& Junior & 192 & 48 \\
& Senior & 42 & 10 \\
\hline & Sum & 400 & 100 \\
\hline
\end{tabular}

As can be seen from Table 1, a total of 400 university students, 100 male and 300 female, from four different faculties have participated in the study. 76 students were freshman, 90 were sophomore, 192 were junior and 42 were senior. 234 students were from education faculty, 56 from Faculty of Administrative and Economic Sciences, 49 from Faculty of Science and Arts and 61 students from the Faculty of Dentistry.

\section{Research Instrument and Procedure}

Young Parenting Inventory (YPI)

Young Parenting Inventory (YPI) was developed by Young (1994) and adopted to Turkish by Soygüt, Çakır and Karaosmanoğlu (2008). The original form and the Turkish translated form of YPI consisted of 72 items, which were same for both mother and father, grouped under two sections. YPI consists of 10-factor structure. Each factor defines a parenting perception. The scale is rated on a Likert-type scale where "1" means "completely untrue" and "6" means "describes him/her perfectly".

In this study, the overall internal consistency coefficient of Young Parenting Inventory Mother Form (YPI-M) was found to be .92. On the other hand, the overall internal consistency coefficient of Young Parenting Inventory Father Form (YPI-F) was found to be .93 .

\section{Parental Bonding Instrument (PBI)}

The original form of PBI, which was developed by Parker, Tupling and Brown (1979) and adopted to Turkish by Kapçı and Küçüker (2006), consisted of 25 items, which were same for both mother and father, grouped under two sections, and 'care' and 'protection/control' dimensions. The scale was answered using 4-points Likert type scale where " $0=$ does not apply at all to $4=$ applies very well".

In this study, the internal consistency coefficient of Parental Bonding Instrument Mother Scale (PBI-M) was found to be .85. The overall internal consistency coefficient of Parental Bonding Instrument Father Scale (PBI-F) was found to be .88 . 


\section{Brief Symptom Inventory (BSI)}

BSI, which was developed by Deragotis (1992) and adopted to Turkish by Şahin and Durak (1994), is the short form of SCL 90-R scale, and it consists of 53 items. The scale makes measurements in nine sub-dimensions, it is an inventory with 5 points-Likert type ranking (0-not at all, 1-a little, 2-moderate, 3-consederably and 4-extremely). In the Turkish version of the inventory, nine-factor structure has been transformed into a fivefactor structure and these dimensions were identified as anxiety, depression, negativeself, somatisation, and hostility.

In this study, the overall internal consistency coefficient of Brief Symptom Inventory (BSI), which consists of 53 items and 5 sub-dimensions, was found to be .95

\section{Data Collection}

After obtaining the required permissions, the scales were applied to the students by the researchers, in a single session, at the specified classrooms of the selected faculties. A total of 450 applications of BSI, PBI and YPI were performed, however the data of 40 students were found to be insufficient for statistical analysis because they did not answer most of the items and their data were excluded from the study. In addition, 10 students answered PBI and YPI for only their mother or father, this might be caused one of their parent's death, parents' divorce or the students' negative attitudes towards one of their parents, thus the data of these 10 students were also excluded from the study.

Data Analysis

SPSS 21.00 software was used for data analysis. Frequency, mean and multiple linear regression analysis were performed. Frequency analysis was used to examine the distribution of the workgroup according to variables. Mean analysis was used to calculate arithmetic means, standard deviations and percentages of university students' parenting perceptions, parental attachment styles and psychological symptoms. Multiple linear regression analysis was used to determine the parenting perceptions and parental attachment styles that predict psychological symptoms.

\section{FINDINGS}

\section{Regression Findings about the Prediction of Psychological Symptoms According to Perceived Parenting}

The parenting perceptions that predicted university students' depression symptoms are given in Table 2.

Table 2: Parenting Perceptions that Predicts Depression

\begin{tabular}{llllll}
\hline Depression & $B$ & $S E B$ & $\beta$ & $t$ & \multicolumn{1}{l}{$p$} \\
\hline Constant & 6.852 & 1.787 & & 3.835 & .000 \\
Pessimistic/fearful mother & .904 & .166 & .270 & 5.454 & .000 \\
Overprotective/worrywart father & .277 & .073 & .180 & 3.785 & .000 \\
Emotionally divesting father & .157 & .054 & .142 & 2.886 & .004 \\
\hline
\end{tabular}

$n=400, R=.398, R^{2}=.159, F=24.805, p<.01$ 
As can be seen from Table 2, pessimistic/fearful mother, overprotective/worrywart father and emotionally divesting father perceptions predict the depression meaningfully and in positive direction $\left(R=.398, R^{2}=.159, F(24.805), p<.01\right)$. It can be said that $16 \%$ of the depression's total variance can be explained with these three parenting perceptions.

The parenting perceptions that predicted university students' anxiety symptoms are given in Table 3.

Table 3: Parenting Perceptions that Predicts Anxiety

\begin{tabular}{llllll}
\hline Anxiety & $B$ & $S E B$ & $\beta$ & $t$ & $p$ \\
\hline Constant & 3.032 & 1.347 & & 2.251 & .025 \\
Pessimistic/fearful mother & .661 & .126 & .254 & 5.259 & .000 \\
Overprotective/worrywart father & .259 & .056 & .216 & 4.618 & .000 \\
Emotionally divesting mother & .169 & .048 & .167 & 3.511 & .000 \\
\hline
\end{tabular}
$n=400, R=.417, R^{2}=.173, F=27.636, p<.01$

As can be seen from Table 3, pessimistic/fearful mother, overprotective/worrywart father and emotionally divesting mother perceptions predict the anxiety meaningfully and in positive direction $\left(R=.417, R^{2}=.173, F(27.636), p<.01\right)$. It can be said that $17 \%$ of the anxiety's total variance can be explained with these three parenting perceptions.

The parenting perceptions that predicted university students' negative-self symptoms are given in Table 4.

Table 4: Parenting Perceptions that Predicts Negative-self

\begin{tabular}{llcccc}
\hline Negative-Self & $B$ & $S E B$ & $\beta$ & $t$ & $p$ \\
\hline Constant & 3.476 & .921 & & 3.775 & .000 \\
Pessimistic/fearful mother & .645 & .120 & .270 & 5.386 & .000 \\
Belittling /captious mother & .242 & .066 & .184 & 3.667 & .000 \\
\hline
\end{tabular}

$n=400, R=.380, R^{2}=.145, F=33.483, p<.01$

As can be seen from Table 4, pessimistic/fearful mother and belittling/captious mother perceptions predict the negative-self meaningfully and in positive direction $(R=.380$, $R^{2}=.145, F(33.483), p<.01$.). It can be said that $15 \%$ of the negative-self's total variance can be explained with these two parenting perceptions.

The parenting perceptions that predicted university students' somatization symptoms are given in Table 5.

Table 5: Parenting Perceptions that Predicts Somatization

\begin{tabular}{llllll}
\hline Somatization & $B$ & $S E B$ & $\beta$ & $t$ & $p$ \\
\hline Constant & 2.005 & .904 & & 2.217 & .027 \\
Pessimistic/fearful mother & .330 & .093 & .182 & 3.540 & .000 \\
Overprotective/worrywart father & .147 & .040 & .176 & 3.656 & .000 \\
Belittling /captious mother & .135 & .051 & .135 & 2.628 & .009 \\
\hline
\end{tabular}

$n=400, R=.345, R^{2}=.119, F=17.843, p<.01$

As can be seen from Table 5, pessimistic/fearful mother, overprotective/worrywart father and belittling /captious mother perceptions predict the somatization meaningfully 
and in positive direction $\left(R=.345, R^{2}=.119, F(17.843), p<.01\right)$. It can be said that $12 \%$ of the somatization's total variance can be explained with these three parenting perceptions.

The parenting perceptions that predicted university students' hostility symptoms are given in Table 6.

Table 6: Parenting Perceptions that Predicts Hostility

\begin{tabular}{lccccc}
\hline Hostility & $B$ & SEB & $\beta$ & $t$ & $p$ \\
\hline Constant & 3.937 & .668 & & 5.890 & .000 \\
Pessimistic/fearful mother & .226 & .069 & .169 & 3.280 & .001 \\
Belittling /captious mother & .120 & .038 & .163 & 3.164 & .002 \\
Overprotective/worrywart father & .085 & .030 & .139 & 2.875 & .004 \\
\hline
\end{tabular}

$n=400, R=.333, R^{2}=.111, F=16.410, p<.01$

As can be seen from Table 6, pessimistic/fearful mother, belittling/captious mother and overprotective/worrywart father perceptions predict the hostility meaningfully and in positive direction $\left(R=.333, R^{2}=.111, F(16.410), p<.01\right)$. It can be said that $11 \%$ of the hostility's total variance can be explained with these three parenting perceptions.

\section{Regression Findings about the Prediction of Psychological Symptoms According to Parental Attachment Styles}

The parental attachment styles that predicted university students' depression symptoms are given in Table 7.

Table 7: Parental Attachment Styles that Predicts Depression

\begin{tabular}{llllll}
\hline Depression & $B$ & $S E B$ & $\beta$ & $t$ & $p$ \\
\hline Constant & 40.112 & 2.404 & & 16.684 & .000 \\
Father care/control & -.302 & .050 & -.282 & -6.028 & .000 \\
Mother protection & -.599 & .118 & -.238 & -5.099 & .000 \\
\hline
\end{tabular}

$n=400, R=.396, R^{2}=.157, F=36.744, p<.01$

As can be seen from Table 7, caring/controlling behaviors of the father and protecting behaviors of the mother predict the depression meaningfully and in negative direction $\left(R=.396, R^{2}=.157, F(36.410), p<.01\right)$. It can be said that $16 \%$ of the depression's total variance can be explained with these two dimensions.

The parental attachment styles that predicted university students' anxiety symptoms are given in Table 8. 
Table 8: Parental Attachment Styles that Predicts Anxiety

\begin{tabular}{llllll}
\hline Anxiety & $B$ & $S E B$ & $\beta$ & $t$ & $p$ \\
\hline Constant & 33.706 & 2.277 & & 14.801 & .000 \\
Mother care/control & -.295 & .049 & -.285 & -6.033 & .000 \\
Father protection & -.476 & .095 & -.235 & -4.986 & .000 \\
\hline$n=400, R=.411, R^{2}=.169, F=40.169, p<.01$ & & & & \\
\hline
\end{tabular}

As can be seen from Table 8, caring/controlling behaviors of the mother and protecting behaviors of the father predict the anxiety meaningfully and in negative direction $\left(R=.411, R^{2}=.169, F(40.169), p<.01\right)$. It can be said that $17 \%$ of the anxiety's total variance can be explained with these two dimensions.

The parental attachment styles that predicted university students' negative-self symptoms are given in Table 9

Table 9: Parental Attachment Styles that Predicts Negative-self

\begin{tabular}{llllll}
\hline Negative-Self & $B$ & $S E B$ & $\beta$ & $t$ & $p$ \\
\hline Constant & 28.005 & 2.089 & & 13.404 & .000 \\
Mother care/control & -.191 & .060 & -.201 & -3.191 & .002 \\
Father protection & -.326 & .088 & -.176 & -3.706 & .000 \\
Father care/control & -.121 & .048 & -.158 & -2.511 & .012 \\
\hline
\end{tabular}

$n=400, R=.412, R^{2}=.170, F=26.921, p<.01$

As can be seen from Table 9, caring/controlling behaviors of the mother and protecting, and caring/controlling behaviors of the father predict the negative-self meaningfully and in negative direction $\left(R=.412, R^{2}=.170, F(26.921), p<.01\right)$. It can be said that $17 \%$ of the negative-self's total variance can be explained with these three dimensions.

The parental attachment styles that predicted university students' somatization symptoms are given in Table 10.

Table 10: Parental Attachment Styles that Predicts Somatization

\begin{tabular}{llllll}
\hline Somatization & $B$ & $S E B$ & $\beta$ & $t$ & $p$ \\
\hline Constant & 17.074 & 1.336 & & 12.779 & .000 \\
Mother protection & -.330 & .065 & -.243 & -5.060 & .000 \\
Father care/control & -.113 & .028 & -.195 & -4.059 & .000 \\
\hline
\end{tabular}

$n=400, R=.333, R^{2}=.111, F=24.768, p<.01$

As can be seen from Table 10, protecting behaviors of the mother and caring/controlling behaviors of the father predict the somatization meaningfully and in negative direction $\left(R=.333, R^{2}=.111, F(24.768), p<.01\right)$. It can be said that $11 \%$ of the somatization's total variance can be explained with these two dimensions.

The parental attachment styles that predicted university students' hostility symptoms are given in Table 11 . 
Table 11: Parental Attachment Styles that Predicts Hostility

\begin{tabular}{llllll}
\hline Hostility & $B$ & $S E B$ & $\beta$ & $t$ & $p$ \\
\hline Constant & 15.608 & 1.217 & & 12.829 & .000 \\
Mother care/control & -.106 & .026 & -.200 & -4.061 & .000 \\
Father protection & -.195 & .051 & -.189 & -3.828 & .000 \\
\hline
\end{tabular}

$n=400, R=.306, R^{2}=.094, F=20.484, p<.01$

As can be seen from Table 11, caring/controlling behaviors of the mother and protecting behaviors of the father predict the hostility meaningfully and in negative direction $\left(R=.306, R^{2}=.094, F(20.484), p<.01\right)$. It can be said that $10 \%$ of the hostility's total variance can be explained with these two dimensions.

\section{DISCUSSION and CONCLUSION}

Regarding the perceived parenting styles that predict psychological symptoms, pessimistic/fearful mother, overprotective/worrywart father and belittling/captious mother perceptions usually predict psychological symptoms positively. The items grouped under pessimistic/fearful parent factor, are the ones that belong to the schema of pessimism. It has been suggested that the effect of the mother, who is the primary caregiver, is bigger on the formation of the idea that outer world is dangerous and unsecure schema (Bruce et al., 2006). Soygüt et al. (2008) have found that the parenting perceptions showing maximum positive correlations with depression were belittling/captious mother, ruling/former mother, overprotective/worrywart mother and belittling/captious father. Again in the same study, the parenting perceptions that showed maximum positive correlations with anxiety were found to be belittling/captious mother, overprotective/worrywart mother, pessimistic/fearful mother, and ruling/former father. Even though the results are similar, in this study it has been found that pessimistic/fearful-belittling/captious mother and overprotective/worrywart father perceptions are more predictive on the symptoms.

Within the context of parental attachment styles, it has been found that the shift of the parental behaviors from care/control dimension to the protection dimension is a factor preventing the emergence of psychological symptoms. The analysis of how the attachment styles explain each psychological symptom leaded to the following result: the increase of the parents' controlling and protective behaviors predicts all psychological symptoms negatively. In the traditional Turkish family formation, caring and loving the children may be equivalent to ensuring their security and care and desiring a better future for them. In this context, controlling and protective behaviors applied by the parents might be perceived as an indicator of their interest and love, which may have caused these results.

There are studies stating that perceived parenting styles and the effect of parental control on the children's future life may vary among cultures (Dwairy \& Achovi, 2010). Many studies have stated that excessive parental control may cause various psychological disorders, such as depression symptoms and anxiety disorder symptoms, in our country as well as in Western culture, during the periods of adolescence and young adulthood (Düzgün, 1995; Lizardi et al., 1995; Whisman \& Kwon, 1992). However there are 
studies explaining that in the culture where the applied control mechanism is perceived as care and love and this may have negative correlation with psychological disorders (Fişek, 1982; Kağıtçıbaşı, 1990).

Consequently, in this study it has been concluded that, the increase of control and protection focus in the attachment dimension plays a preventive role on the emergence of psychological factors; the applied control and protection may be felt as care and love by the children. At the same time, it has been found that pessimistic/fearfulbelittling/captious mother and overprotective/worrywart father perceptions play the biggest role on the emergence of psychological symptoms.

Since many biological and environmental factors play role on the emergence of psychological symptoms, it is suggested to use different variables in similar future studies.

\section{REFERENCES}

Ainsworth, M. D. S., Blehar, M. C., Waters, E., \& Wall, S. N. (2014). Patterns of attachment: A psychological study of the strange situation. Hove, England: Psychology Press.

Akpınar, E., \& Saatçi, E. (2007). Çukurova üniversitesi öğrencilerinde psikiyatrik belirti taramas1. Türkiye Aile Hekimliği Dergisi, 10(1), 7-13. Retrieved from http://www.turkailehekderg.org/wp-content/uploads/2014/07/c10-s01-01.pdf

Bartholomew, K., \& Horowitz, L. M. (1991). Attachment styles among young adults: a test of a four-category model. Journal of Personality and Social Psychology, 61(2), 226-544. doi: 10.1037/0022-3514.61.2.226

Baumrind, D. (1991). The influence of parenting style on adolescent competence and substance use. The Journal of Early Adolescence, 11(1), 56-95. doi: $10.1177 / 0272431691111004$

Bos, A. E., Huijding, J., Muris, P., Vogel, L. R., \& Biesheuvel, J. (2010). Global, contingent and implicit self-esteem and psychopathological symptoms in adolescents. Personality and Individual Differences, 48(3), 311-316. Retrieved from http://www.sciencedirect.com/science/article/pii/S019188690900436X

Bowlby, J. (1969). Attachment: Volume 1 of Attachment and loss. London, England: Tavistock.

Bowlby, J. (1973). Attachment and loss vol. 2: Seperation, anxiety and anger. London, England: Hogarth Press and Institute of Psycho-Analysis.

Bowlby, J. (1979). The making and breaking of affectional bonds. London, England: Tavistock.

Bruce, A. E., Cole, D. A., Dallaire, D. H., Jacquez, F. M., Pineda, A. Q., \& LaGrange, B. (2006). Relations of parenting and negative life events to cognitive diatheses for depression in children. Journal of Abnormal Child Psychology, 34(3), 310-322. doi: 10.1007/s10802-006-9010-x 
Chorpita, B. F., \& Barlow, D. H. (1998). The development of anxiety: the role of control in the early environment. Psychological bulletin,124(1), 3-21. doi: 10.1037/0033-2909.124.1.3

Conger, R. D., \& Ge, X. (1999). Conflict and cohesion in parent-adolescent relations: Changes in emotional expression from early to mid-adolescence. In M. J. Cox \& J. Brooks-Gunn (Eds.), Conflict and cohesion in families: Causes and consequences (pp. 185-206). Mahwah, New Jersey: Erlbaum.

Demirel, S. A., Eğlence, R., \& Kaçmaz, E. (2011). Üniversite öğrencilerinin ruhsal durumlarının belirlenmesi. Nevşehir Hacı Bektaş Veli Üniversitesi Sosyal Bilimler Dergisi, l(1), 18-29. $\quad$ Retrieved from http://dergipark.ulakbim.gov.tr/nevsosbilen/article/view/1043000027/1043000025

Derogatis, L. R. (1992). Brief Symptom Inventory (BSI) administration, scoring and procedures manual (3rd ed.). Minneapolis, Minnesota: National Computer Systems.

Dopheide, J. A. (2006). Recognizing and treating depression in children and adolescents. American Journal of Health-System Pharmacy, 63(3), 233-243. Retrieved from http://beanifer.tripod.com/sitebuildercontent/sitebuilderfiles/depression.pdf

Düzgün, Ş. (1995). Lise ögrencilerinin psikolojik belirtileri ile ana-baba yutumlar arasındaki ilişkiler (Yayınlanmış doktora tezi). Atatürk Üniversitesi, Erzurum. Retrieved from https://tez.yok.gov.tr/UlusalTezMerkezi/tezSorguSonucYeni.jsp

Dwairy, M., \& Achovi, M. (2010). Parental control: A second cross-cultural research on parenting and psychological adjustment of children. Journal of Child and Family Studies, 19(1), 16-22. doi: 10.1007/s10826-009-9334-2

Fisek, G. (1982). Psychopathology and the Turkish Family: A family systems theory analysis. In Kagitçibaşi (Ed.), Sex roles, family, \& community in Turkey (pp. 295-321). Bloomington, IN: Indiana University Turkish Studies. Retrieved from https://www.jhumansciences.com/ojs/index.php/IJHS/article/view/3555/1693

Hale, W. W., Engels, R., \& Meeus, W. (2006). Adolescent's perceptions of parenting behaviours and its relationship to adolescent Generalized Anxiety Disorder symptoms. Journal of Adolescence, 29(3), 407-417. Retrieved from http://www.sciencedirect.com/science/article/pii/S0140197105000904

Harris, A. E., \& Curtin, L. (2002). Parental perceptions, early maladaptive schemas, and depressive symptoms in young adults. Cognitive Therapy and Research, 26(3), 405-416. doi: 10.1023/A: 1016085112981

Hudson, J. L., \& Rapee, R. M. (2001). Parent-child interactions and anxiety disorders: An observational study. Behaviour research and therapy,39(12), 1411-1427. doi:10.1016/S0005-7967(00)00107-8

Kağıtçıbaşı, Ç. (1990). İnsan, aile, kültür. İstanbul, Türkiye: Remzi Kitabevi.

Kağıtçıbaşı, Ç., \& Öztürk, Ş. (2010). Benlik, aile ve insan gelişimi: Kültürel psikoloji. İstanbul, Türkiye: Koç Üniversitesi Yayınları. 
Kapçı, E. G., \& Küçüker, S. (2006). Ana babaya bağlanma ölçeği: Türk üniversite öğrencilerinde psikometrik özelliklerinin değerlendirilmesi. Türk Psikiyatri Dergisi, 17(4), 286295. Retrieved from http://www.turkpsikiyatri.com/C17S4/makale6.pdf

Karasar, N. (2006). Bilimsel araştırma yöntemi. Ankara, Türkiye: Nobel Yayın Dağıtım.

Kesebir, S., Kavzoğlu, S. Ö., \& Üstündağ, M. F. (2011). Bağlanma ve psikopatoloji. Psikiyatride Güncel Yaklaşımlar,3(2), 214-231. Retrieved from http://dergipark.ulakbim.gov.tr/pskguncel/article/view/5000076372/5000070428

Keskin, G., \& Çam, O. (2008). Ergenlerin ruhsal durumları ve anne baba tutumları ile bağlanma stilleri arasındaki ilişkinin incelenmesi. Anadolu Psikiyatri Dergisi, 9(3), 139147. Retrieved from http://psikiyatridizini.net/articles.aspx ?journalid=4\&year $=2008 \&$ volume $=9 \&$ number $=3$

Kim, Y. H. (2003). Correlation of mental health problems with psychological constructs in adolescence: Final results from a 2-year study. International Journal of Nursing Studies, 40(2), 115-124. doi:10.1016/S0020-7489(02)00037-8

Kim, D. H., \& Yoo, I. Y. (2013). Relationship between attention deficit hyperactive disorder symptoms and perceived parenting practices of school-age children. Journal of Clinical Nursing, 22(7-8), 1133-1139. doi: 10.1111/j.1365-2702.2012.04343.x

Lizardi, H., Klein, D. N., Ouimette, P. C., Riso, L. P., Anderson, R. L., \& Donaldson, S. K. (1995). Reports of the childhood home environment in early-onset dysthymia and episodic major depression. Journal of Abnormal Psychology, 104(1), 132-139. doi: 10.1037/0021-843X.104.1.132

McGinn, L. K., Cukor, D., \& Sanderson, W. C. (2005). The relationship between parenting style, cognitive style, and anxiety and depression: Does increased early adversity influence symptom severity through the mediating role of cognitive style?. Cognitive Therapy and Research,29(2), 219-242. doi: 10.1007/s10608-0053166-1

Pachler, M. C., \& Hamrin, V. (2005). Child and adolescent depression: Review of the latest evidence-based treatments. Journal of Psychosocial Nursing and Mental Health Service, 1, 54-61. Retrieved from https://dialnet.unirioja.es/servlet/articulo?codigo=1080437

Parker, G., Tupling, H., \& Brown, L. B. (1979). A parental bonding instrument. British Journal of Medical Psychology, 52(1), 1-10. doi: 10.1111/j.2044-8341.1979.tb02487.x

Perris, C., Arrindell, W. A., \& Eisemann, M. (1994). Parenting and psychopathology (Vol. 21). New York: Wiley.

Pierce, T., Baldwin, M. W., \& Lydon, J. E. (1997). A relational schema approach to social support. In Sourcebook of social support and personality (pp. 19-47). New York: Plenum.

Rapee, RM., Spence, SH., Cobham, V. (2000). Kaygll çocuğa yardım: Anne babalar için aşamalı klavuz (Çev. R. Baykaldı). Ankara, Türkiye: Arkadaş Yayınevi.

Rothbard, J. C., \& Shaver, P. R. (1994). Continuity of attachment across the life span. In M. B. Sperling \& W. H. Berman (Eds.), Attachments in adults: Clinical and developmental perspectives (pp. 31-71). New York: Guilford. 
Saluja, G., Iachan, R., Scheidt, P. C., Overpeck, M. D., Sun, W., \& Giedd, J. N. (2004). Prevalence of and risk factors for depressive symptoms among young adolescents. Archives of pediatrics \& adolescent medicine, 158(8), 760-765. doi:10.1001/archpedi.158.8.760.

Soygüt, G., Çakır, Z., \& Karaosmanoğlu, A. (2008). Ebeveynlik biçimlerinin değerlendirilmesi: Young Ebeveynlik Ölçeğinin psikometrik özelliklerine ilişkin bir değerlendirme. Türk Psikol Dergisi, 11(22), 17-30. Retrieved from http://www.turkpsikolojiyazilari.com/PDF/TPY/22/17-30.pdf

Steinberg, L., Lamborn, S. D., Darling, N., Mounts, N. S., \& Dornbusch, S. M. (1994). Over-time changes in adjustment and competence among adolescents from authoritative, authoritarian, indulgent, and neglectful families. Child development, 65(3), 754-770. doi: 10.1111/j.1467-8624.1994.tb00781.x

Şahin, N. H., \& Durak, A. (1994). Kısa semptom envanteri: Türk gençleri için uyarlanmas1. Türk Psikoloji Dergisi,9(31), 44-56. Retrieved from http://www.turkpsikolojidergisi.com/PDF/TPD/31/04.pdf

Thompson, R. A. (1991). Attachment theory and research. In M. Lewis (Ed.), Child and adolescent psychiatry: A comprehensive textbook (pp. 100-108). Baltimore, Maryland: Williams \& Wilkings.

Ulusoy, D., Demir, N. Ö., \& Baran, A. G. (2005). Ergenlik döneminde intihar algısı: lise son sınıf gençliği örneği. Edebiyat Fakültesi Dergisi, 22(1), 259-270. Retrieved from http://www.edebiyatdergisi.hacettepe.edu.tr/index.php/EFD/article/viewFile/134/98

Van Gastel, W., Legerstee, J. S., \& Ferdinand, R. F. (2009). The role of perceived parenting in familial aggregation of anxiety disorders in children. Journal of Anxiety Disorders, 23(1), 46-53. doi:10.1016/j.janxdis.2008.03.014

Vasey, M. W., \& Dadds, M. R. (2001). The developmental psychopathology of anxiety. New York: Oxford University Press.

Whisman, M. A., \& Kwon, P. (1992). Parental representations, cognitive distortions, and mild depression. Cognitive Therapy and Research, 16(5), 557-568. Retrieved from http://link.springer.com/article/10.1007/BF01175141

Young, J.E. (1994). Young Parenting Inventory. New York: Cognitive Therapy Center of New York.

Young, J. E., Klosko, J. S., \& Weishaar, M. E. (2003). Schema therapy: A practitioner's guide. New York: Guilford Press.

Turkish Abstract

Üniversite Öğrencilerin Ebeveyn Algıları ve Ana-Babaya Bağlanma Stillerinin Üniversite Öğrencilerinde Görülen Psikolojik Semptomları Yordama Gücü

$\mathrm{Bu}$ araştırma, üniversite öğrencilerinin sahip oldukları ebeveyn algıları, ana-babaya bağlanma stilleri ve gösterdikleri psikolojik semptomlar arasındaki ilișkileri inceleyen, hangi ebeveyn algılarının ve ana-babaya bağlanma stillerinin hangi psikolojik semptomları yordadığını belirlemeyi hedefleyen ilişkisel tarama modelinde bir çalışmadır. Araştırmanın çalışma grubunu 
400 üniversite öğrencisi oluşturmaktadır. Veri toplama aracı olarak Young Ebeveynlik Ölçeği (YEBÖ), Ana-Babaya Bağlanma Ölçeği (ABBÖ) ve Kısa Semptom Envanteri (KSE) kullanılmıştır. Çalışma grubunda en yaygın olarak görülen semptomlar depresyon, hostilite ve anksiyete olarak belirlenmiştir. Çalışma grubunda en yaygın olarak görülen ebeveyn algılarının anne için koşullu/başarı odaklı anne ve kuralcı/kalıplayıcı anne algıları olduğu; baba için ise koşullu/başarı odaklı baba ve kapalı/duygularını bastıran baba algıları olduğu bulgularına ulaşılmıştır. Psikolojik semptomları en çok yordayan ebeveyn algıları kötümser/endişeli anne, küçümseyici/kusur bulucu anne ve aşırı koruyucu/evhamlı baba algıları olarak bulunmuştur ve semptomları pozitif yönde anlamlı düzeyde yordamaktadır. Bağlanma stilleri kapsamında ise ebeveynlere hem ilgi/kontrol hem de koruma boyutlarında bağlanmanın semptomları negatif yönde ve anlamlı düzeyde yordadığı, koruma boyutunun ilgi/kontrol boyutuna göre semptomların oluşmasında daha önleyici bir bağlanma stili olduğu ve kültürümüzde ebeveynlerin aşırı koruyucu davranışlarının çocuklar tarafından ebeveynlerinin kendilerine olan sevilerinin ve ilgilerinin göstergeleri olarak algılanıyor olabileceği belirlenmiştir. Elde edilen bulgular ilgili literatür çerçevesinde tartış1lmıştır.

Anahtar Kelimeler: ebeveyn-çocuk ilişkileri, bağlanma, bilişsel şemalar, psikolojik problemler, ana-babaya bağlanma

\section{French Abstract}

La Force Prophétique de Rôle parental Perçu et Styles d'Attachement Parentaux sur Symptômes Psychologiques parmi Université turque Students

Cette étude a pour but d'examiner les relations entre le rôle parental perçu, des styles d'attachement parentaux et des symptômes psychologiques parmi des étudiants universitaires turcs et il a aussi pour but de découvrir qui a perçu le rôle parental et des styles d'attachement parentaux prévoient les symptômes psychologiques qui ont été mesurés. Cette étude est une recherche quantitative et utilise le design de recherche comparatif causal. L'échantillon de cette étude consiste en 400 étudiants universitaires. Le jeune Stock de Rôle parental, l'Instrument de Lien Parental et le Stock de Symptôme Bref ont été utilisés pour rassembler des données. Le dépressif, l'hostilité et des symptômes d'anxiété ont été déterminés comme les symptômes psychologiques les plus répandus parmi l'échantillon. Cette étude est une recherche quantitative et utilise le design de recherche comparatif causal. L'échantillon de cette étude consiste en 400 étudiants universitaires. Le jeune Stock de Rôle parental, l'Instrument de Lien Parental et le Stock de Symptôme Bref ont été utilisés pour rassembler des données. Le dépressif, l'hostilité et des symptômes d'anxiété ont été déterminés comme les symptômes psychologiques les plus répandus parmi l'échantillon.

Mots Clés: relation parent-enfant, lien, plans cognitifs, problèmes psychologiques, attachement parental

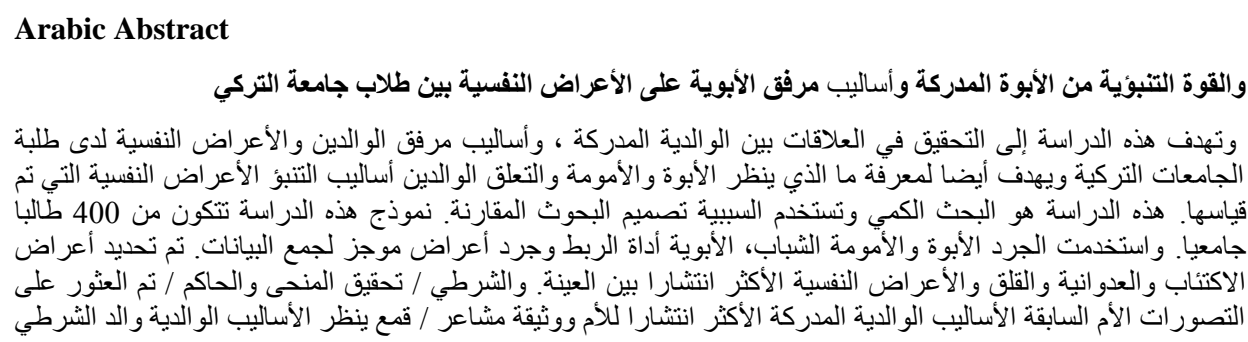




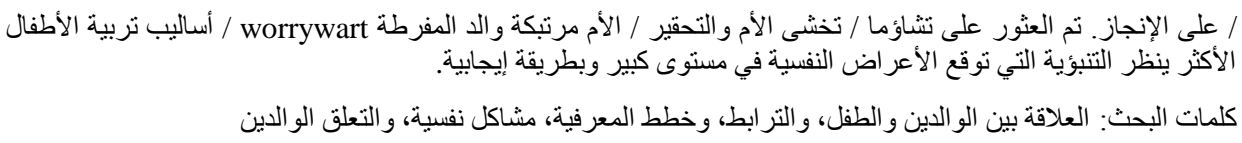

\section{German Abstract}

Die Predictive Stärke wahrgenommener Erziehung und Elternbindungsstile auf psychische Symptome unter türkischen Studenten der Universität

Diese Studie hat zum Ziel, die Beziehungen zwischen der gefühlten Erziehung, Elternbindungsstile und psychische Symptome unter türkischen Studenten zu untersuchen, und es soll auch herausfinden, welche Arten Erziehung und Eltern Bindung vorhersagen psychische Symptome wahrgenommen, die gemessen wurden. Diese Studie ist eine quantitative Forschung und nutzt kausalen vergleichende Forschungsdesign. Die Probe dieser Studie besteht aus 400 Studenten. Junge Eltern Inventar, Elterliche Bindungsinstrument und Kurze Symptom Inventar wurden zum Sammeln von Daten verwendet. Die depressive, Feindseligkeit und Angst Symptome wurden als die am weitesten verbreitete psychische Symptome unter der Probe bestimmt. Die bedingte/leistungsorientiert und herrschenden/ehemalige Mutter Wahrnehmungen wurden die am häufigsten wahrgenommen Erziehungsstile für Mutter und dem bedingten/leistungsorientiert und in der Nähe/verdrängten Gefühle wahrgenommen Erziehungsstile für Vater gefunden. Pessimistische/ängstliche Mutter, belittling/spitzfindig Mutter und überängstlich/worrywart Vater waren die prädiktive wahrgenommen Erziehungsstile, die die psychischen Symptome in ein signifikantes Niveau und in einer positiven Art und Weise vorhersagen gefunden.

Schlüsselwörter: eltern-kind-beziehung, bindung, kognitive systeme, psychische probleme, die elterliche bindung

\section{Malaysian Abstract \\ Kekuatan ramalan Persepsi Ibu Bapa dan Attachment Styles Ibu Bapa pada Gejala psikologi dalam kalangan Pelajar Universiti Turki University}

Kajian ini bertujuan untuk mengkaji hubungan antara ibu bapa, Attachment Styles ibu bapa dan gejala psikologi dalam kalangan pelajar universiti Turki dan ia juga bertujuan untuk mengetahui yang mana persepsi dan Attachment Styles keibubapaan meramalkan gejala psikologi yang diukur. Kajian ini merupakan kajian kuantitatif dan menggunakan reka bentuk kajian perbandingan sebab akibat. Sampel kajian ini terdiri daripada 400 pelajar universiti. Young Parenting Inventory, Parental Bonding Instrument dan Brief Symptom Inventory telah digunakan untuk mengumpul data. Kemurungan, permusuhan dan kebimbangan gejala ditentukan sebagai gejala psikologi yang paling lazim di kalangan sampel. Bersyarat/berorientasikan pencapaian dan ketetapan $/$ bentuk persepsi ibu ditemui gaya keibubapaan yang paling lazim dilihat bagi ibu dan bersyarat/berorientasikan pencapaian berorientasikan dan perasaan tertutup dilihat menjadi persepsi gaya keibubapaan untuk bapa. Pesimis takut ibu, memperkecilkan ibu dan terlalu melindungi bapa didapati gaya keibubapaan yang paling ramalan dilihat yang meramalkan gejala psikologi dalam tahap yang penting dan dengan cara yang positif.

Kata Kunci: hubungan ibu bapa dan anak, ikatan, skim kognitif, masalah psikologi, lampiran ibu bapa 